\title{
BANKING INTEGRATION AND EFFICIENCY CONVERGENCE IN BALTIC COUNTRIES IN POST-CRISIS PERIOD
}

\author{
Mihăiță-Cosmin POPOVICI 1
}

DOI: 10.1515/tjeb-2015-0008

\begin{abstract}
We investigate banking efficiency in Baltic countries over the period 2007-2011 during one of the biggest financial crisis. The global economic crisis began in December 2007 with the loss of investor confidence in the U.S. securitized mortgages that led to a liquidity crisis that prompted a substantial injection of capital into financial markets by the U.S. Federal Reserve, the Bank of England and European Central Bank. Baltic countries joined the EU in 2004, during the largest wave of accession. Estonia is a member of the eurozone since 2011, Latvia since 2014 and Lithuania adopted euro in 2015. We use Data Envelopment Analysis (DEA) - a nonparametric method in operations research and economics for the estimation of production frontiers. It is used to empirically measure productive efficiency of decision-making units (or DMUs) for a sample of banks in a highly concentrated banking system. The aim of the paper is to show the evolution of the banking efficiency in the Baltic countries over the period 2007-2011 by using Malmquist index. Our goal is to highlight the evolution of efficiency and we want to answer the research question "How banking efficiency evolved after the financial crisis?" Results show a slight improvement in banking efficiency over the period 2010 - 2011 due to improved management of the inputs, but further research is needed to gain a clearer picture of the phenomenon.
\end{abstract}

Keywords: $\quad$ Efficiency; convergence; Baltic countries; integration.

JEL Classification: G01; G21.

${ }^{1}$ PhD Student, Alexandru loan Cuza University of Iasi, Romania. 
Popovici, M. C. (2014).

Banking integration and efficiency convergence in Baltic countries in post-crisis period

\section{Introduction}

The European banking sector has gone through a number of profound changes in the last two decades.

On 1st of November 1993, the Maastricht Treaty came into force and the European Union was formally established. In the last decade of the 20th century and the beginning of the 21st century, twelve countries had gone through the transition to European Union integration. This process has rather proved to be not an easy task, as it involved policy reforms at the microeconomic and macroeconomic environment. The new member states have significant differences in their market structure compared with older member states: banking intermediation is the key source of access to financial resources, the financial intermediation is at lower levels, the banking market display higher levels of concentration and a higher degree of foreign involvement in the financial sector. (European Central Bank, 2005).

The new European landscape created by the European Union lead to an internal market for goods, services, labor and capital. The process of European integration is not over, and the financial crisis laid bare a number of weaknesses in the institutional setup and brought the process of financial integration to a halt.

Recent crisis in the global financial system has severe effects on the banking sector from all over the world, with many too large to fail banks suffering losses and being forced to accept government bailout or to raise additional capital. Investors, depositors, and supervision agencies failed to discipline banks appropriately, and the crisis began.

We used a Data Envelopment Analysis (DEA) model for measuring banking efficiency in Baltic countries because of the advantages of if: it works well with small samples, like the one used in our research. Other advantages of this technique are that it does not require any assumptions to be made about the distribution of inefficiency and it does not require a particular functional form of the data in determining the most efficient banks. We expect that banking efficiency will not improve significantly (Thoraneenitiyan \& Avkiran, 2009) due to employee's dismissal after the banking crisis.

„In autumn 2008, the world entered the worst financial crisis and the most severe economic downturn since the end of the Second World War. Since spring 2009, the financial market conditions have improved, an economic growth has resumed in most countries, albeit very moderately in many advanced economies" (Macys, 2012: 1). There is no consensus among scholars about the post-crisis period, Latvia and Estonia have experienced decline in GDP in 2008 - 2009, Lithuania only in 2009 (Eurostat data). The post-crisis period is influenced by country and time period, especially developed countries have felt the effects of crisis in 2008

DE GRUYTER OPEN 
Popovici, M. C. (2014).

Banking integration and efficiency convergence in Baltic countries in post-crisis period

and in 2009 began to rebound, Baltic countries felt the crisis in 2008 - 2009 (Lithuania only in 2009) and began to rebound in 2010.

Latvia is the newest member of the euro zone, in particularly, the second country that adopted euro after the financial crisis started (after Estonia in 2011) and Lithuania wants to adopt the single currency in the beginning of 2015. The other four states that adopted euro after 2007, Cyprus, Malta, Slovakia and Slovenia were in ERM II before de crisis started. The Baltic States had the highest growth rates in Europe between 2000 and 2007. Estonia is among the ten most liberal economies in the world and in 2006 World Bank classified it as a high-income economy. The global economic crisis hit hard these countries, in 2009 unemployment rates rose to 13.7 in Lithuania, 17.3\% in Latvia and 13.8\% in Estonia. In addition, the real GDP fell by $14.8 \%$ in Lithuania, $18 \%$ in Latvia and $13.9 \%$ in Estonia in the same year. Estonia succeeded in keeping its debt levels one of the lowest in the EU, Latvia and Lithuania are in a more difficult situation.

Our study is conducted considering these issues and the impact of the financial crisis on bank efficiency. The paper will fill the gap in the literature on banking efficiency in the post-crisis in the Baltics countries. This study is divided into six parts: introduction, literature review, model specification and methodology, data and variables used, empirical results and the last part, conclusion.

\section{Literature review}

The efficiency of banks has been widely and extensively studied in the past few decades. For banks, efficiency implies improved profitability, greater amounts of funds channeled through the system, better prices and service quality for consumers, and greater safety in terms of improved capital buffers in absorbing risk (Berger et al. 1993). In the last years, many studies have been conducted in Europe and other parts of the world. The problem is that few researchers studied developing countries. Sanjeev, 2006 investigated that Indian Government has implemented a series of reforms in the last fifteen years, and a study was necessary to show the effect and improvement in banking efficiency. Data Envelopment Analysis was used for measuring technical efficiency of banks in Indian banking sector. The results showed that the reforms were implemented with success, and the efficiency of the banks has improved and the foreign banks have better efficiency scores than private sector and public sector banks.

De Jonghe and Vennet, 2008 used a modified Tobin's Q ratio as a measure of bank franchise value. This method is used to discriminate between the market structure and efficient-structure hypotheses in which differences in banks horizontal and vertical differentiation strategies are controlled for. The banks with better management or

\section{DE GRUYTER} OPEN
Timisoara Journal of Economics and Business | ISSN: 2286-0991 | www.tjeb.ro Year 2014 | Volume 7 | Issue 2 | Pages: 134-146 
Popovici, M. C. (2014).

Banking integration and efficiency convergence in Baltic countries in post-crisis period

production technologies possess a long-run competitive advantage. Banks with a large market share in a concentrated market are able to generate non-competitive rents. Even in the member states of the European Union, country-specific macroeconomic variables have a significant impact on bank performance. For the study, a set of 183 banks from 15 European countries between 1997 and 2004 is used.

Mamatzakis et. al., 2008 studied cost and profit efficiency in the banking systems of ten member states of the European Union over the period 1998 - 2003 by using the stochastic frontier approach. A low level of cost and profit efficiency was observed in the sample, foreign banks outperform state-owned and private-owned banks in terms of profit efficiency, but results are less clear in the case of cost efficiency. Several steps have been made towards financial integration and towards enhancing integration in the banking systems from the ten EU member states, but many issues still remain to be tackled.

Staikouras et al., 2008 lead an investigation over the new European banking landscape over the period 1998 - 2005 to examine the differences between old and new member states revealed that there are significant differences. Indeed total operating expenses for the ten new member states have declined during the period, but they remain at a higher level compared to the old member states. The operational performance of banks is positively related to the quality of the loan portfolio, the bank's size and the development of the banking system and it is negatively related to liquidity and the loan ratio.

Ncube, 2009 examined the cost and profit efficiency of banks in South Africa by using a stochastic frontier model to determine both cost and profit efficiency of four large and four small, South African-based banks. The study showed that South African banks have significantly improved their cost efficiencies between 2000 and 2005. However, efficiency gains on profitability, over the same period, have not been significant. No bank was found to be superior to another in terms of achieving efficiency gains in cost reduction and profitability. A weak positive correlation was found to exist between the cost and profit efficiencies, with the most cost efficient banks also being most profit efficient. With regard to bank size, cost efficiency declined with increasing bank size.

Unde and Heimeshoff, 2009 used a balance sheet from banks across the EU25 over the period from 1997 to 2005 to provide empirical evidence that national banking market concentration has a negative impact on European banks financial soundness. The market concentration has a positive impact on banks ROAA capital ratios and the volatility of the ROAA. The banks from the Eastern European countries exhibits a lower level of competitive pressure and a higher percentage of government-owned banks are more prone to financial fragility.

DE GRUYTER OPEN
Timisoara Journal of Economics and Business | ISSN: 2286-0991 | www.tjeb.ro Year 2014 | Volume 7 | Issue 2 | Pages: 134-146 
Popovici, M. C. (2014).

Banking integration and efficiency convergence in Baltic countries in post-crisis period

Koutsomanoli-Fillippaki et al., 2009 investigated the bank efficiency and productivity change by using directional technology distance function. This technique is used for Central and Eastern European countries over the period 1998 - 2003. After the progress on institutional and structural reforms, the productivity for the region has improved. The foreign banks have better results that domestic private and state-owned banks both in terms of productivity growth and efficiency. In conclusion, the productivity change in Central and Eastern countries is driven by technological change rather than efficiency change.

Andries and Cocris, 2010 used both methods, Data Envelopment Analysis (DEA) and Stochastic Frontier Analysis (SFA) was targeted on the main banks in Romania, the Czech Republic and Hungary for the period 2000-2006. The banks from these countries reach low levels of technical efficiency and cost efficiency, the main factors that influence efficiency are quality of the assets, banks size, annual inflation rate, banking reform, form of ownership and interest rate liberalization.

Fethi and Pasiouras, 2010 measured bank performance by using operational research (O.R.) and artificial intelligence techniques. Data Envelopment Analysis is one of the most widely applied O.R. technique in the field. The variables used in studies differ significantly. Some researchers start with a large list of variables and then use statistical screening or dimension reduction to obtain a reduced set of variables. Andries, 2011 used two different approaches, a parametric method, Stochastic Frontier Analysis and a non-parametric method, Data Envelopment Analysis, in central and east European countries, one researcher showed that the average efficiency of banks grew between 2004 and 2008. The results may be due to increased competition from other member states of European Union and extensive legislative changes that boosted banks efficiency.

Huang et. al, 2011 uses Fourier flexible cost function with time-varying technical efficiency under the framework of the meta-frontier. The meta-cost frontier is used because of the existence of multiple technologies. The sample use data for 689 commercial banks in nine European countries, Austria, Belgium, Denmark, France, Germany, Italy, Portugal, Spain, and Switzerland. Only banks with at least three years of observed data are selected. The popular intermediation approach is used, which views banks as an intermediary between depositors and borrowers.

Andries and Capraru, 2012 studied the competition in the banking system of the EU27 as a whole, but also in both old member states and new member states was investigated using two measures of competition, the Learner Index and H-statistics for a panel of 923 commercial banks from 27 countries of the European Union for the period $2001-2009$. Only banks with information available for at least 5 years were included, and those with missing, negative or zero values were excluded. The results showed that competition in the EU27 had higher scores in 2009 in comparison with 2001. This increase in competition

DE GRUYTER OPEN
Timisoara Journal of Economics and Business | ISSN: 2286-0991 | www.tjeb.ro Year 2014 | Volume 7 | Issue 2 | Pages: 134-146 
Popovici, M. C. (2014).

Banking integration and efficiency convergence in Baltic countries in post-crisis period

could be explained by the entry of foreign banks and deregulation. The decrease of competition in old member states could be explained by a decrease of interest rate and the orientation of European multinational banks to markets with many more possibilities to increase their profits. Chortareas et. al., 2012 studied another sample of 22 EU countries over the period 2000 - 2008 was investigated by using Data Envelopment Analysis, in the first stage of the analysis, then two distinct accounting ratios to capture the costs of intermediation and cost effectiveness. The efficiency of banks operations can be improved By strengthening capital restrictions and official supervisory powers. Banks from countries with less concentrated and more developed systems tend to have relatively higher levels of efficiency.

Hadad et. al, 2012 used a new approach, SORM SBM DEA for analyzing the efficiency of Indonesian banking system during the period 2003-2007. This method was chosen because standard DEA models fail to allow for additional potential input reductions. The Indonesian system has 130 banks with a combined balance sheet of over 213 billion $\$$. It contains, at the end of 2007, 5 state-owned banks, 35 foreign exchange private banks, 11 foreign banks, 17 joint-venture banks, 36 non-foreign exchange private banks and 26 regional government-owned banks. At the end of the 1997, there were 222 banks, but a post-financial crisis consolidation took place. The results show that the estimated efficiency scores are very sensitive to the choice of methodology used for dealing with negative numbers.

Paradi and Zhu, 2013 published at the beginning of the 2013, a survey on bank branch efficiency and performance research using DEA. The banking sector from many countries has been the object of DEA analyzed by various researchers. The papers survey 80 DEA applications in 24 countries with a specifical focus on banks branches. There is significant diversity among studies in terms of the input-output selection. The business environment is dynamic and developing more reliable DEA models will be an important topic in future bank branch studies. We want to thrown light on the efficiencies of banks in developing countries, particularly, in Baltic countries, effects of the financial crisis and in highly concentrated banking systems.

\section{Model Specification and Methodology}

Data Envelopment Analysis is a mathematical programming technique for the development of production frontiers and the measurement of efficiency relative to those frontiers. Each bank in the sample is assigned an efficiency score between zero and one, banks with higher scores are more efficient that those with lower scores. The main advantages of DEA are that it works well with small samples, as the one used in our research and ability to accommodate a multiplicity of inputs and outputs. Other advantages of this technique are that it does not require any assumptions to be made about the distribution of inefficiency and it does not require a particular functional form of the data in determining the most

\section{DE GRUYTER OPEN}


Popovici, M. C. (2014).

Banking integration and efficiency convergence in Baltic countries in post-crisis period

efficient banks. It is also useful because it takes into consideration returns to scale in calculating efficiency, allowing for the concept of increasing or decreasing efficiency based on size and output levels. DEA has drawbacks, it assumes data to be free of measurement error, and it is sensitive to outliers. Coelli et al. (2005) also point out that: (i) having few observations and many inputs and/or outputs will result in many firms appearing on the DEA frontier; (ii) treating inputs/outputs as homogenous commodities when they are heterogeneous may bias the results; (iii) not accounting for differences in the environment may give misleading results; (iv) standard DEA does not control for multi-period optimization or risk managerial decision making, Another drawback of this technique is that model specification and inclusion/exclusion of variables can affect the results (Berg, 2010).

We had to choose from two types of DEA models: input or output oriented according to whether the focus is on input minimization while keeping a given output level or output maximization given levels of the inputs. We wanted to answer the question: By how many quantities should the inputs be reduced to give us the current levels of outputs? The second choice was the output orientation, which can answer the question: At the current level of the inputs, by how much can the output quantities be increased? (Sanjeev, 2006, p. 8).

Following the trend of recent banking literature, we employ an input-oriented DEA approach because banks are typically under pressure to minimize cost, especially in crisis times, where outputs cannot be controlled because are normally constrained by the market demand.

There are two options for DEA models: Constant Returns-to-Scale model (CCR) was the first used historically and it was widely applied for several years. This model does not differentiate between pure "technical" inefficiencies and inefficiencies due to non-constant (increasing or decreasing) returns-to-scale effects, for example due to constraints in finance, competition, etc. The input-oriented and output-oriented scores produced are the same in this case, although other results differ.

The second type is Variable Returns-to-Scale model (VRS) which is commonly used today and allows the decomposition of the "global" efficiency (that is, the CCR efficiency) into a "local" pure technical efficiency (the score, in this model) and a scale efficiency factor.

DEA is a method based on linear programming, and the method of relatively evaluating the efficiency of DMU, such as a set of firms etc. Usually, when considering the problem of efficiency, it can be expressed as (efficiency) = (output) / (input). In this formula, the efficiency becomes higher when input value is smaller, and output value is larger. However, since the influences which each input gives to each output may differ if the number of input or output increases, it may be unable to evaluate simply by the efficiency $\theta=$ (sum of

\section{DE GRUYTER OPEN}


Popovici, M. C. (2014).

Banking integration and efficiency convergence in Baltic countries in post-crisis period

output) / (sum of input). By DEA, the maximum of the efficiency of each DMU can be calculated by applying weight so that each parameter may become advantageous. Moreover, as a fundamental idea, accepting the property of each DMU and not limiting the optimal solution to one, it allows enhancing efficiency in the form that is best for each DMU. The CRS linear programming problem can be easily modified to account for VRS by adding the convexity constraint: $N 1^{\top} \lambda=1$ to provide:

$$
\begin{aligned}
& \min _{\theta, \lambda} \theta, \\
& s t-y_{i}+Y \lambda \geq 0, \\
& \theta x_{i}-X \lambda \geq 0, \\
& N 1^{\prime} \lambda=1 \\
& \lambda \geq 0,
\end{aligned}
$$

Where $\mathrm{N} 1$ is an Nx1 vector of ones.

This approach forms a convex hull on intersecting planes which envelope the data points more tightly than the CRS conical hull and thus provides technical efficiency scores which are greater than or equal to those obtained using the CRS model (Coelli, 2005).

The input-oriented and output-oriented scores produced are not the same in this case. In our research, we use the input-oriented DEA with Variable Returns to Scale developed by Banker et. al. (1984) because allows that the production technology of banks may exhibit increasing, decreasing or constant returns to scale.

\section{Data and Variables Used}

The data source used in the analysis of bank efficiency in Baltic countries are the annual reports of banks. The sample used information regarding seven banks in three countries: Estonia (3), Latvia (5) and Lithuania (3) for the period 2007 - 2011. Two banks (SwedBank and SEB) are present in all three countries.

There is currently no consensus regarding the inputs and outputs that must be used in analyzing commercial bank efficiency (Berger \& Humphrey, 1997). The five predominant approaches for defining the inputs and outputs for bank efficiency analysis are the (1) intermediation approach, (2) production approach, (3) assets approach, (4) user cost approach, and (5) value-added approach. The appropriateness of which of the five approaches to use depends on the circumstances (Tortosa-Ausina, 2002). The intermediation approach is argued to be particularly appropriate for banks where most activities consist of turning large deposits and funds purchased from other financial institutions into loans or financing and investments (Favero \& Papi, 1995). We used the intermediation approach (Sanjeev, 2006) version of inputs of outputs: deposits and

\section{DE GRUYTER} OPEN 
Popovici, M. C. (2014).

Banking integration and efficiency convergence in Baltic countries in post-crisis period

operating costs for inputs variable and loans, investments and other income for outputs variable. The variable other income includes securities and loans to financial institutions.

The banking system from Estonia is highly concentrated; only four banks hold $86 \%$ of total assets: SwedBank, SEB Pank, NORDEA, and DANSKE. SwedBank is a modern bank from Sweden with branches in all Baltic countries and others states. SEB is a leading financial services group from Nordic countries. Nordea is the largest financial services group in Nordic and Baltic Sea region. DANSKE is the largest bank in Denmark and one of the leading financial groups in northern Europe. Latvia has a concentrated banking system, the top five banks held $68 \%$ of total assets: SwedBank, SEB Banka, ABLV Bank, DNB Bank and Rietumu Banka. ABLV is one of the largest private banks in the Baltic countries. DNB is the largest financial group in Norway and one of the top universal banks in Latvia. Rietumu Banka is a commercial bank and one of the largest private banks in the Baltic States. Lithuania has the same characteristics, top three banks held $54 \%$ of total assets: SEB Bankas, SwedBank and DNB Bankas. The two financial groups, SwedBank and SEB are present in all three countries.

\section{Empirical Results}

For DEA modeling, we used DEAP, version 2.1. All values are converted to millions of Euro from national currencies, except Estonia that adopted the euro. We used an input oriented DEA model because the focus was on input minimization while keeping the outputs at the same level, particularly in crisis period. This approach is used because the outputs are constrained by market demand.

In Table 1 we compute descriptive statistics for our database. We have four variables: loans and other income as outputs, and deposits and operational costs as inputs. All variables have Skewness over 0 which means that most values are concentrated on the left of the mean, with extreme values to the right. Kurtosis for all variables is under 3 , we have a platykurtic distribution, flatter than a normal distribution with a wider peak.

DE GRUYTER OPEN 
Popovici, M. C. (2014).

Banking integration and efficiency convergence in Baltic countries in post-crisis period

Table 1. Descriptive statistics

\begin{tabular}{lcccc}
\hline \multicolumn{1}{c}{ Year } & Loans & Other income & Deposits & Operational costs \\
\hline Mean & 28686.03 & 3080.23 & 12804.54 & 421.58 \\
Standard Error & 7528.65 & 843.82 & 3120.37 & 107.52 \\
Median & 3178.34 & 318.96 & 1779.22 & 44.21 \\
Mode & 135445.04 & 20760.68 & 54686.28 & 1994.65 \\
Standard Deviation & 55834.01 & 6257.96 & 23141.33 & 797.44 \\
Sample Variance & 31174371.63 & 39162063.85 & 535521426.9 & 635923.57 \\
Kurtosis & 0.97 & 2.49 & 1.01 & 0.91 \\
Skewness & 1.70 & 1.99 & 1.71 & 1.69 \\
Range & 153311.8 & 20756.54 & 66518.18 & 2130.92 \\
Minimum & 670.81 & 4.13 & 494.78 & 23.48 \\
Maximum & 153982.61 & 20760.68 & 67012.96 & 2154.4 \\
\hline
\end{tabular}

Source: Author`s calculations

In Table 2 we have Malmquist index summary of annual means. We divided the sample into two periods: first one from 2008 to 2009, the crisis period for Baltic countries, and the second one from 2010 to 2011, the post-crisis period. We have five components: technical efficiency change (effch), technological change (techch), pure efficiency change (pech), scale efficiency change (sech) and total factor productivity change (efpch). Note that Total Factor Productivity Change $=$ Technological Change $x$ Technical Efficiency Change and

Technical Efficiency Change $=$ Scale Efficiency $x$ Pure Efficiency Change.

Table 2. Malmquist index summary of annual means

\begin{tabular}{cccccc}
\hline Year & Effch & Techch & Pech & Sech & Efpch \\
\hline $2(2008)$ & 0.984 & 0.927 & 0.980 & 1.004 & 0.912 \\
$3(2009)$ & 1.035 & 0.989 & 1.067 & 0.970 & 1.024 \\
mean & 1.0095 & 0.958 & 1.0235 & 0.987 & 0.968 \\
$4(2010)$ & 1.028 & 0.974 & 1.022 & 1.006 & 1.002 \\
$5(2011)$ & 1.025 & 1.001 & 1.015 & 1.010 & 1.026 \\
mean & 1.0265 & 0.9875 & 1.0105 & 1.008 & 1.014 \\
\hline
\end{tabular}

Source: Output DEAP 2.1

DE GRUYTER OPEN
Timisoara Journal of Economics and Business | ISSN: 2286-0991 | www.tjeb.ro Year 2014 | Volume 7 | Issue 2 | Pages: 134-146 
Popovici, M. C. (2014).

Banking integration and efficiency convergence in Baltic countries in post-crisis period

In Table 2, total factor productivity change is higher in the second period, post-crisis, indicating that, on average, banks experienced gains in total productivity after the crisis. Examining the decomposition of total factor productivity change into technological change and technical efficiency change, the predominance of the technical efficiency change is noticeable across both periods of time and suggests that the improved management of the inputs played the big role in total factor productivity change.

The Malmquist index results also identify a difference between pure efficiency change and scale efficiency change. The results suggest that some banks were operating on a scale that was not efficient in both sub-periods. This finding suggests that some banks may still be operating at sub-optimal scale, implying a case for greater concentration in banking in the three countries through mergers and acquisitions.

\section{Conclusion}

In our study, we investigate banking efficiency in Baltic countries over the period 2007 during one of the biggest financial crisis. We use Data Envelopment Analysis (DEA) for a sample of 11 banks in a highly concentrated banking system and Malmquist Index. One of the advantages of DEA is that it works well with small samples, as the one used in our research, but Coelli et al. (2005) also point out that having few observations and many inputs and/or outputs will result in many firms appearing on the DEA frontier.

From our results, we can see a slight improvement in banking efficiency in the post-crisis period, indicating that, on average, banks experienced gains in total productivity after the crisis. Examining the decomposition of total factor productivity change into technological change and technical efficiency change, the predominance of the technical efficiency change is noticeable across both periods of time and suggests that the improved management of the inputs played the big role in total factor productivity change. The assumption that we will not see a significant improvement in efficiency due to people dismissal is invalidated.

Also, the difference between pure efficiency change and scale efficiency change suggests that some banks were operating on a scale that was not efficient in both time periods and further mergers and acquisitions are recommended.

Acknowledgement:

This work was cofinanced from the European Social Fund through Sectorial Operational Programme Human Resources Development 2007-2013, project number POSDRU/159/1.5/S/142115 „Performance and excellence in doctoral and postdoctoral research in Romanian economics science domain".

\section{DE GRUYTER} OPEN
144
Timisoara Journal of Economics and Business | ISSN: 2286-0991 | www.tjeb.ro Year 2014 | Volume 7 | Issue 2 | Pages: 134-146 
Popovici, M. C. (2014).

Banking integration and efficiency convergence in Baltic countries in post-crisis period

\section{References}

Andries, A.M. (2011). The Determinants of Bank Efficiency and Productivity Growth in the Central and Eastern European Banking Systems. Eastern European Economics, 49 (6), 38-59. doi:10.2753/eee0012-8775490603

Andries, A.M., \& Capraru, B. (2012). Competition and efficiency in EU27 banking systems. Baltic Journal of Economics, 12(1), 41-60. doi:10.1080/1406099x.2012.10840510

Andries, A.M., \& Cocris, V. (2010). A comparative analysis of the Efficiency of Romanian Banks. Romanian Journal of Economic Forecasting, 4.

Banker, R.D., Charnes, A., \& Cooper, W.W. (1984). Some Models for Estimating Technical and Scale Inefficiencies in Data Envelopment Analysis. Management Science, 30(9), 1078-1092. doi:10.1287/mnsc.30.9.1078

Berg, S. (2010). Water Utility Benchmarking: Measurement, Methodology, and Performance Incentives. International Water Association.

Berger, A., \& Humphrey, D. (1997). Efficiency of Financial Institutions: International Survey and Directions for Future Research. European Journal of Operational Research, 98 (2), 175-212. doi:10.1016/s0377-2217(96)00342-6

Berger, A., Hunter, W., \& Timme, S. (1993). The Efficiency of Financial Institutions: A Review and Preview of Research Past, Present and Future. Journal of Banking and Finance, 17(2-3), 221-249. doi:10.1016/0378-4266(93)90030-h

Chortareas, G.E., Girardone, C., \& Ventouri. A. (2012). Bank supervision, regulation and efficiency: Evidence from the European Union. Journal of Financial Stability, 8(4), 292-302. doi:10.1016/j.jfs.2011.12.00

Coelli, T.J., Prasada Rao, D.S., O’Donnell, C.J., \& Battese, G.E. (2005). An Introduction to Efficiency and Productivity Analysis. Second edition. USA: Springer.

De Jonghe, O., \& Vennet, R. V. (2008). Competition versus efficiency: What drives franchise values in European banking? Journal of Banking \& Finance, 32(9), 1820-1835. doi:10.1016/j.jbankfin.2007.12.009

European Central Bank (2005). Banking structures in the new EU Member States. European Central Bank.

European Central Bank (2012). Financial integration in Europe. European Central Bank.

Favero, C., \& Papi, L. (1995). Technical Efficiency and Scale Efficiency in the Italian Banking Sector: A Non-Parametric Approach. Applied Economics, 27(4), 385-395. doi:10.1080/00036849500000123

Fethi, M.D., \& Pasiouras, F. (2010). Assessing bank efficiency and performance with operational research and artificial intelligence techniques: A survey. European Journal of Operational Research, 204(2), 189-198. doi:10.1016/j.ejor.2009.08.003

Hadad, M.D., Hall, M.J.B., Kenjegalieva, K.A., Santoso, W., \& Simper, R. (2012). A new approach to dealing with negative numbers in efficiency analysis: An application to the Indonesian banking sector. Expert Systems with Applications, 39(9), 8212-8219. doi:10.1016/j.eswa.2012.01.145

Huang, T.H., Chiang, L.C., \& Chen, K.C. (2011). An empirical study of bank efficiency and technological gaps in European banking. The Manchester School, 79(4), 839-860. doi:10.1111/j.1467-9957.2010.02178.x

DE GRUYTER OPEN 
Popovici, M. C. (2014).

Banking integration and efficiency convergence in Baltic countries in post-crisis period

Koutsomanoli-Filippaki, A., Margaritis, D., \& Staikouras, C. (2009). Efficiency and productivity growth in the banking industry of Central and Eastern Europe. Journal of Banking \& Finance, 33(3), 557-567. doi:10.1016/j.jbankfin.2008.09.009

Macys, D. (2012). The Crisis and Economic Recovery in Baltic Countries. International Journal of Humanities and Social Science, 19(2), 202-209.

Mamatzakis, E., Staikouras, C., \& Koutsomanoli-Filippaki, A. (2008). Bank efficiency in the new European Union member states: Is there convergence? International Review of Financial Analysis, 17(5), 1156-1172. doi:10.1016/j.irfa.2007.11.00

Ncube, M. (2009). Efficiency of the banking sector in South Africa. University of the Witwatersrand

Paradi, J. C., \& Zhu, H. (2013). A survey on bank branch efficiency and performance research with data envelopment analysis. Omega, 41(1), 61-79. doi:10.1016/j.omega.2011.08.01

Sanjeev, G. (2006). Data Envelopment Analysis (DEA) for Measuring Technical Efficiency of Banks. Vision: The Journal of Business Perspective, 10(1), 13-27. doi:10.1177/097226290601000102

Staikouras, C., Mamatzakis, E., \& Koutsomanoli-Filippaki, A. (2008). An empirical investigation of operating performance in the European banking landscape. Global Finance Journal, 19(1), 32-45. doi:10.1016/j.gfj.2008.01.001

Thoraneenitiyan, N., \& Avkiran, N. (2009). Measuring the impact of restructuring and country-specific factors on the efficiency of post-crisis East Asian banking systems: Integrating DEA with SFA. Socio-Economics Planning Sciences, 43(4), 240-252. doi:10.1016/j.seps.2008.12.002

Tortosa-Ausina, E. (2002). Banks Cost Efficiency and Output Specification. Journal of Productivity Analysis, 18 (3), 199-222.

Uhde, A., \& Heimeshoff, U. (2009). Consolidation in banking and financial stability in Europe: Empirical evidence. Journal of Banking \& Finance, 33 (7), 1299-1311. doi:10.1016/j.jbankfin.2009.01.006 